\title{
Heritage Marketing in Tourism
}

\author{
Gorazd Sedmak, University of Primorska, UP FTŠ Turistica
}

Članek tematizira koncept marketinga dediščine. Osnovna ideja marketinga dediščine je, da se med ponudbo in povpraševanjem doseže »poštena « izmenjava, ki zadovolji potrebe oz. želje obiskovalcev/turistov in interese upravljalca/ponudnika dediščine, obenem pa se ohranja fizično in simbolno vrednost dediščine.

Ključne besede: trženje dediščine, kulturna dediščina, turizem, turistična ponudba

This paper addresses the concept of marketing in heritage. The basic idea of heritage marketing is to achieve a "fair" exchange between the supply and demand, which meets the needs/wishes of visitors/ tourists and the interests of managers/providers of heritage, while at the same time preserving the physical and symbolic value of the heritage.

Keywords: heritage marketing, cultural heritage, tourism, tourist offer

A

lthough heritage marketing as a concept has already been present in the world for at least thirty years, ${ }^{\mathrm{I}}$ in the last decade I have met several humanities experts who were rather suspicious of the very idea of heritage marketing. "Heritage is something that needs to preserved for future generations, studied and interpreted, and certainly not exploited for making profits!” In principle, I agree. I am also aware that inappropriate use of heritage by the tourism industry, which often happens in practice and which leads to distortion, loss of authenticity, physical or symbolic degradation or even destruction, is harmful. However, sensible and professional valorization of heritage in tourism can be a source of revenue, which can be invested in preservation and protection of heritage and offers opportunities for new jobs for local people. In many cases, tourism even helps intangible heritage to survive or even resuscitates already

E.g. Church, Marketing. forgotten heritage. ${ }^{2}$ And, last but not least, who are the "future generations" who will be entitled to fully enjoy the heritage, and whether tourists are also among them?

In everyday life, people often equate marketing with promotion or advertising. Thus, in the present time, when we are "bombarded" with advertisements at every step, marketing is perceived as something negative, aggressive. However, promotion is only a part (and not even the most important) of marketing. Marketing is (according to American Marketing Association; https://www.ama.org/AboutAMA/Pages/Definition-of-Marketing.aspx) >the activity, set of institutions, and processes for creating, communicating, delivering, and exchanging offerings that have value for customers, clients, partners, and society at large $\ll$. It is a process of searching information, designing and implementing a product concept, pricing poli-

2 Cohen "Authenticity and Commodization," 382 
cy making, market communication and the distribution of ideas, services and goods in order to achieve the individual goals of customers / users (usually by meeting their needs) and the goals of the organization. It should be stressed that these goals are not necessarily of financial nature. To the above, »socially responsible marketing « adds also the consideration of the interests of other stakeholders (local communities, employees) and concern for the natural environment. As Hannahs (2003) establishes in the context of underwater architectural heritage: $\gg$ It is not a part of archaeological discipline to provide the general public with more and better opportunities to access cultural resources «, nor they have been trained to do it. That is the task for other - marketing - professions. DiMaggio (in Rentschler, 20Io) similarly claims that nonprofit institutions are not non-market institutions.

Chhabra (2010) in her book »Sustainable Marketing of Cultural and Heritage Tourism« defines marketing as: "The process sought to exchange ideas, relationships and products with various public stakeholders and stakeholders with goals to enhance attendance, income, education and interactive engagement with customers while promoting sustainable environments and society interests at large for the enjoyment of both current and future generations."

Of course, there are some specifics of heritage marketing comparing to the marketing of ordinary market goods. Heritage bears an important cultural value for the local community, and is quantitatively and spatially, in some cases also time-limited. It is vulnerable - both in physical and symbolic terms. However, taking into account these specifics, we can benefit much by using marketing tools, such as market segmentation, targeting and positioning, marketing plan, branding, etc. for tourism valorization of heritage.

Let us look for example just the marketing plan. Despite its apparent banality, this tool can constitute a good basis for reflection and decision-making. The stages of the plan are analy-

Veverka, "Marketing Basics." sis of the internal and external environment, determination of objectives, selection of marketing strategies, implementation and monitoring, respectively assessment of the performance of the activities.

Thus, we should begin with the analysis of our organization and its resources. We need to ask ourselves where are we currently, and where we would like to be, what resources represent our strengths and what are our weaknesses (is that the personnel or their competences, finances or anything else)? It may be the heritage itself - not all heritage can be developed into the tourist attraction. ${ }^{4}$ Or, if we go one step further: "worth of seeing" does not always mean "worth of visiting". The visit is related to some financial and non-financial costs (time, stress, etc.), which can discourage potential visitors from visiting our site. In the second phase, we need to examine our market and non-market external environment. Who are our potential visitors, how many are they, and what their characteristics are (where do they come from, how can they be segmented, what are their motives, "purchase" habits, etc.), who represents our competition, with whom we can connect/collaborate, what the legal framework of our organization is and how the local community perceives us. Next comes the goals setting. They should not be too many, they must be clearly set (if possible quantified) and time-defined. Some possible goals are: increase in the number of visitors, restriction of visits, better informed local community, more income, changed structure of visitors, de-seasonalization, etc. In order to achieve these goals, it is necessary to specify the operators, the necessary resources and activities (e. g. joining some associations, collecting the fee, advertising, merchandising, etc.). The final stage is, of course, controlling/assessment and possible corrections/adaptation of the plan. The key stage of the marketing plan is goals setting. They must not be contrary to the interests of any of the relevant stakeholders. With (possibly) necessary adjustments, such an approach enables effi-

4 Apostolakis, "Convergence Process in Heritage Tourism." 
cient and holistic action in all forms of heritage valorization in tourism.

To conclude, I would like to draw attention on some often-overlooked facts from the field of heritage valorization in tourism. If local people do not know that something is their heritage, in the eyes of tourists this is not heritage but history. Most tourists want to get to know the heritage only superficially in a funny way; ${ }^{6}$ motives for visiting heritage attractions are very heterogeneous (in addition to the basic four Es - entertainment, escape, aesthetics, education, these are also "an opportunity to socialize", "to kill time", "random" visit, nostalgia ...). ${ }^{7}$ Heritage marketing is mainly about being able to see the heritage (also) through the eyes of tourists.

\section{Povzetek}

Čeprav se o marketingu dediščine govori in piše že vsaj trideset let, ga humanisti (če že) sprejemajo dokaj zadržano. Del te zadržanosti gre gotovo pripisati nerazumevanju vloge marketinga pri turistični valorizaciji dediščine. Marketing ni aktivnost, ki bi imela dediščino za surovino, iz katere se kujejo dobički. Gre za znanja in veščine ter nabor orodij, s pomočjo katerih se dosegajo različni cilji, povezani z vključevanjem dediščine v turistično ponudbo. Pomembno je, da te cilje, ki so lahko zelo raznoliki (in nikakor ne samo finančni), določa tisti, ki upravljala z dediščino. Osnovna ideja marketinga dediščine je, da se med ponudbo in povpraševanjem doseže »poštena izmenjava, ki zadovolji potrebe oz. želje obiskovalcev/turistov in interese upravljalca/ponudnika dediščine, obenem pa se ohranja fizično in simbolno vrednost dediščine.

\section{Summary}

Although the concept of heritage marketing has been already present for at least thirty years, the humanists (if they do) accept it quite suspiciously. Partially, this reticence can be ascribed to the lack of understanding of the role of marketing in the tourism valorization of heritage. Marketing is not an activity that would use herit-

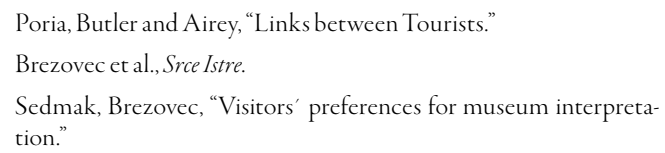

age as a raw material for making profits. It is about knowledge and skills and a set of tools that help in achieving different goals related to the integration of heritage into the tourist offer. It is important that these goals, which can be very diverse (and by no means only financial), are determined by those who manage the heritage. The basic idea of heritage marketing is to achieve a "fair" exchange between the supply and demand, which meets the needs/wishes of visitors/tourists and the interests of managers/providers of heritage, while at the same time preserving the physical and symbolic value of the heritage.

\section{Bibliography}

Apostolakis, Alexandros. "The Convergence Process in Heritage Tourism.” Annals of Tourism Research 30 (2003): 795-812.

Brezovec, Aleksandra, Gorazd Sedmak, Ksenija

Vodeb and Petra Kavrečič. Srce Istre:

kulturna dediščina skozi oči turistične javnosti. Koper: Založba Annales, 2007. Chhabra, Deepak. Sustainable Marketing of Cultural and Heritage Tourism. New York: Routledge, 2010.

Church, Nancy J. Marketing for nonprofit cultural organizations. Plattsburgh, New York: Clinton-Essex-Franklin Library System, 1986.

Cohen, Erik. "Authenticity and

Commodization in Tourism." Annals of

Tourism Research Is (1988): 37I-86.

Hannnahs, Todd, "Underwater Parks versus

Preserves: Data or Access.” In Submerged

Cultural Resourse Management, eds. James

D. Spirek and Della A. Scott-Ireton, 5-i6.

New York: Kluwer Academic/Plenum

Publishers, 2003.

Poria, Yaniv, Richard Butler and David Airey.

"Links between Tourists, Heritage, and

Reasons for Visiting Heritage Sites."

Journal of Travel Research 43 (2004): 1928.

Rentschler, Ruth. "Museum and Performing Arts Marketing: A Climate of Change." The Journal of Arts Management, Law, 
and Society 28, no. I (2010): 83-96. doi: I0.1080/10632929809597280.

Sedmak, Gorazd and Aleksandra Brezovec.

"Visitors' preferences for museum interpretation: identifying and targeting market segments." Academica turistica: tourism \& innovation journal 2 (2017):

I 4 I-5O.

Veverka, John A. "Marketing Basics for Interpretive \& Heritage Sites and Attractions - It's all about the visitors. " (2013). https://portal.uni-freiburg.de/ interpreteurope/service/publications/ recommended-publications/veverka_ marketing_basics.pdf.
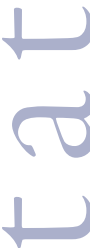

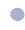
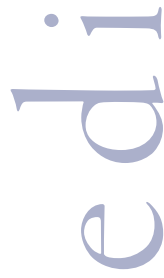

(
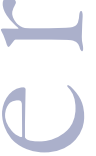